\title{
Qualitative Review of Stories Told: Anecdotes of CFO - CEO Relationships
}

\author{
Theodore Brown Sr., Ph.D. \\ Professor of Management and Leadership \\ Oakwood University \\ Department of Business and Information Systems \\ School of Business
}

\begin{abstract}
The basis of this qualitative examination was incited by the notion that the perceptions of Seventh-day Adventist (SDA) Local Conference leadership substantially effects how the relationships of Chief Financial Officers (CFOs/Treasurers) and Chief Executive Officers (CEOs/Presidents) are viewed and function as members of their conference leadership team . In the past, Chief Financial Officers (CFOs) and Chief Executive Officers (CEOS) have historically functioned in their own professional executive compartments within their organizations rather than partnering together as cooperative teammates. The $21^{\text {st }}$ Century's, however, has forever changed how CFOs and CEOs relate to each other in the workplace due to the inception of governmental regulations called the Sarbanes-oxley Act which was passed to address major corruption in large USA businesses and organizations, major non-compliance in accounting practices, extensive financial reporting fraud, institutional mismanagement, board governance, CFO and CEO accountability. The impact of SarbanesOxley has also influenced the relational practices of CFOs and CEOs in Seventh-day Adventist (SDA) conferences. A Mixed-Methods sequential exploratory research design was used with primary data for this study purposefully selected, collected and analyzed (coding, patterns, trends and themes) from qualitative focus group interviews with four local conference CFOs and CEOs, $\mathrm{N}=8$, located in the United Stated of America (USA). Discussion and Conclusion are explored and disclosed, and the Implications of CFO and CEO relationship on organizational effectiveness, efficiency, and climate are presented.
\end{abstract}

Keywords: Board Governance, CEO (Chief Executive Officer/President), CFO (Chief Financial Officer/Treasurer), Executive Board Members, General Conference (GC), leadership, North American Division (NAD), perceptions, CFO-CEO relationships, Sarbanes-Oxley Act, Seventhday Adventists (SDA)

\section{INTRODUCTION}

In prior decades, Chief Financial Officers (CFOs) and Chief Executive Officers (CEOs) have functioned in their own professional executive compartments within their organizations rather than partnering together as cooperative teammates (Berry, 2015). The 21 $1^{\text {st }}$ Century's, however, has forever changed how CFOs and CEOs relate to each other in the workplace due to the inception of governmental regulations called the Sarbanes-Oxley Act of 2002 (Aquilio, 2016; Joseph, 2015) which was passed to address major corruption in large USA businesses and organizations, major non-compliance in accounting practices, extensive financial reporting fraud, institutional mis-management, board governance, and CFO/CEO accountability (Franklin, 2016; Shapiro, 2015; Mahadeva, 2015).

According to Grove (2016), organizational health, effectiveness, vitality (Inkinen, 2016; Apenko and Chernobaeva, 2016; Verma and Dhar, 2016) and efficiency (Al-Amin, Makarem and Rosko, 2016; Horne, 2016; Epure and Lupu, 2012) has been directly linked to the positive working 
relationship between the CEO and CFO in the organization, whereas, Moulton (2016) characterized it in terms of the entities' financial well-being, and Caruso (2015) as good financial leadership.

\section{LITERATURE}

\section{Understanding Organizational Effectiveness and Efficiency}

Organizational effectiveness and efficiency primarily depends upon an executive's leadership style inclusive of transformational and visionary leadership (Taylor, Cornelius and Colvin, 2014; Walter, 2014) along with the institution's human resource department and areas of employee commitment, loyalty, performance, satisfaction, technological adeptness and trust (Sadeh, 2017; Ullah, and Yasmin, 2013; Shiri, 2012). These critical factors tends to directly impact an organization's competiveness, growth, innovation, marketability, profitability and sustainability. (Dembowski, 2013).

Organizational policies, procedures, values and interpersonal treatment enhance managerial effectiveness of managers leading to positivity and productivity in organizations (Malbasic, Marimon and Mas-Machuca, 2016; Srivalli and Kota, 2016; Rangriz and Soltanieh, 2015; Yildiz, 2014). When employees believe that their organization values their contributions and cares about their welfare, employees will work more efficiently to save the organization time and money. They will find ways to be more efficient in doing their jobs. If organization shows a profit at the end of the year these employees may receive a percentage or bonuses in return for saving the organization money. Non-financial rewards, such as training and development, workshops can also enhance organizational effectiveness. Organizational effectiveness and efficiency examines and measures the relationship between management evaluations, employees performance and working towards the objectives, goals and mission of the organization (Horne, 2016; Lin and Orvis, 2016; Salhieh and Abu-Doleh, 2015)

Organizations may wish to shape desired employee behavior in an effort to help them in knowing their responsibility in contributing to and enhancing the overall effectiveness and efficiency of their organization. In other words, their task significance and how it impacts the organization (Glamuzina, 2015). The CEO and CFO may also want to look at achieving organizational goals through accountability and respect from employees (Kerns, 2015).

\section{CEO/CFO Impact on Organizational Effectiveness and Efficiency}

There should be authentic and open communication (Vercic and Zerfass, 2016) between the CEO's and CFO's office. Within an organization they cannot operate independently of each other, or in silos if they want to achieve success for their organization. The primary concern for these officers should be every aspect of what is happening internally in the organization as well as the external environment; especially in the aspect of organizational effectiveness and efficiency.

A crucial responsibility of the CEO, as the leader of the organization (Ode, 2016) and CFO is to foster and facilitate a good and healthy working relationship with each other (Baker, 2016; Grove, 2016; Caruso, 2015). They must serve and work together as partners providing support, leadership and encouragement not only to one another and the leadership team, but also to all employees to ensure that the organization is fulfilling its mission and achieving its performance and productivity goals (Schiff, 2016). In order to make certain that organizational effectiveness and efficiency goals and standards are being realized, these two must communicate and work together in harmony with each other and the leadership team to maximize shareholders' value, wealth and organizational profits in a transformative manner. 


\section{CEO/CFO Relationships in SDA Context}

The impact of the Sarbanes-Oxley Act (Howell, 2015) has also influenced the relational practices of CFOs and CEOs in Seventh-day Adventist (SDA) conferences largely derived from the trending exponential growth in global membership and financial revenues (Adventist World - NAD 2013, p. 5). The effective leadership strategies required to lead and manage the conferences has necessitated that CEOs and CFOs work in a more collaborative (Van Niekerk, 2016) strategic partnership (Butcher, 2011) to achieve the mission of the organization. CEOs are expected to provide the visionary leadership for the organization and the CFO is expected to support the vision as they serve as teammates (Westfall, 2015; Taylor, Cornelius and Colvin, 2014).

The NAD Working Policy (2015-2016) and SDA Accounting Manual (2011) underline the operative relationships and positional duties of the CEO (President) and CFO (Treasurer) with the understanding that a positive working chemistry will be developed and nourished (Bartlett, 2016). But there still remains some uncertainty as to whether or not the expectations (Buckingham and Coffman, 1999) and perceptions pertaining to the relationships of CEOs and CFOs in SDA local conferences are understood among conference leadership primarily consisting of CEOs, CFOs and Board Members.

\section{RESEARCH DESIGN}

A mixed methods research design (Creswell, 2014) was used in this study. Creswell (2003) "defines mixed methods research by incorporating the definition that focuses on collecting and analyzing both quantitative and qualitative data in a single study" (p. 210). A sequential exploratory design involving qualitative (Eriksson and Kovalainen, 2008; Nardi, 2003) and quantitative (Elsbach and Bechky, 2009) methods was utilized in the collection and analysis of the data. Pertaining to this paper, qualitative research was used with data purposefully selected, collected and analyzed from interviews with four local conference CFOs and CEOs, $\mathrm{N}=8$, located in the USA.

\section{Abe (CE0) Conference Tends to Impact Relationships}

\section{RESULTS (STORIES TOLD)}

"It depends on the conference you're in and the specific needs of the local conference. There's got to be a good working relationship, a trust factor. There's got to be loyalty between the two or back and forth with the tow where they support each other. A high level of trust and ability to communicate between each other. The treasurer's responsibility is to provide the president with good information."

\section{Ken's (CEO) and Ray (CFO) Just Hang Out Sometimes}

Ken estimated that he and Ray (CFO) spent " 4 to 5 hours a week" in discussing conference business, and "2 to 3 hours per week" in leisure time. Ray stated "we have a strong relationship". I know what's expected of me. Give timely and accurate financial information. Work together, support one another, focus on the right thing. Have a good team."

\section{Lee's Story (CF0) Stay in Your Lane}

"It's important to get to know each other. The more you know someone, the better you can trust them. And certainly that helps us to get to know each other on a very close basis, and that's very important when carrying out some of the very difficult decisions that have to be made."

"The treasurer should report to the president. Make the president aware on a regular basis of where we are financially, where we are with various business transactions that are taking 
place. To be an assistant to the president. Be able to handle the financial side of what the presidents wants to do as the president envisions the conference. To recognize that the president is the person who should have the vision and set forth the plan for the conference."

\section{Sue's Story (CFO) From Watchdog to Watchperson}

"When I first became treasurer, I didn't realize the importance of having, like some of the congenialities that I think I mentioned earlier between the officers (Doing things together with the families outside of the office, and fun related activities, etc.). I looked at my role as being the hammer, you know, the person, and you know, the watchdog. And I think that that made a kind of adversarial type of relationship. But as I have been in it longer, and have worked with people that I've had that kind of good relationship with, I have seen the benefit that it has been to the organization and to me as a person to have that kind of good relationship with the person that I am working with. And, it does something with the people know they can't go to you and get some kind of stuff going behind the back of the president, and vice versa. They know you all are a cohesive unit, and that you are working together. I think it really makes a difference in your conference as to how settled your workers are, how settled your constituents are, that it's kind of calming effect on your field with the officers are working together."

\section{Tom's Story (CE0) Fired in 60 Seconds}

"It happened some years back. The president and the treasurer weren't getting along and the executive committee made the decision one day and, before it was taken, he (the treasurer) said: I cannot serve in this conference if this particular action is voted. Well, it was voted and he said, I can't work here if we're going to do whatever it was, I don't remember what the action was. And the president said (speaking to the treasurer), is that your final decision? And the treasurer said yes it is. And the president said, all in favor of accepting the treasurer's resignation, please raise your hand. And the committee unanimously raised their hands and the treasurer went from being treasurer to out of work in about 60 seconds. That's the best case I know of a treasurer really doing himself in. It's better not to get to far out on a limb like that." According to Tom, the treasurer's intent in that story was not to quit his job, but his lack of clarity and a bad relationship with the president and board did not lend him a second chance. The moral of the story, he stated, is that a treasurer needs to work with the president and board as a team as much as possible.

\section{Ray's Story (CE0) A President's Assassination}

"What I saw was a treasurer who was there a long time and a president who was fairly new. The president had an agenda he wanted to do. A number of the directors in that conference wouldn't, didn't, think it was a good idea so they would just talk to the treasurer about it because the treasurer was there a long time. He knew everybody and had a good relationship with everybody. So instead of the treasurer saying, hey, you got a problem with this, the president's is the boss, he was elected, the constituency elected him, God called him, you need to work with him, kind of like Kind David. So go talk to him about it. He'd just talk to them about it. And then they'd all work together to try and undermine the president. And that's garbage. That is just pure garbage. Uh, then Satan was happy, and nothing got done, and everybody was fighting. And actually the president of a heart attack. And I believe it was stress related. So you go to, if you have a problem with the president, go talk to him. If others have a problem in the office on the team, or pastors or the teachers, you have to encourage them to go to the president. You have to have that working relationship". 


\section{IMPLICATIONS}

Throughout the interview process in gathering these stories, the presidents (CEOs) and treasurers (CFOs) agreed that the relationship between the two had gone through an evolutionally stage from the past to the present and would continue to evolve in the future. In some cases, the presidents and treasurers were not congruent on the "feelings and thoughts" on how to best relate to one another pertaining to expectations, however, they all believed that they should "work together" in a partnering, positive and productive manner that would foster and enhance the achievement and fulfillment of the organization's goals and mission, and build a team-oriented work environment that would grow and strengthen employee loyalty, productivity and satisfaction.

\section{CONCLUSIONS}

This leadership objective between the CEO and CFO would also promote and environment of effectiveness and efficiency in the overall organizational performance in a sustainable manner that would be very meaning to all the conference stakeholders, and of greater importance in reflecting the church mission and modeling as Body of Christ. The quality of CEOs and CFOs relationships significantly impact the organizational outcomes in culture and climate for its internal and external operations. It's critical that these relationships be maximized in the most positive manner possible for the good of the conference and organization on all levels, partnership and subsideries.

\section{References}

Adventist World - NAD (2013, June). Treasurer says north american tithe up 1 percent, 4.4 percent in other regions. p. 5.

Al-Amin, M., Makarem, S. and Rosko, M. (2016, October - December). Efficiency and hospital effectiveness in improving hospital consumer assessment of healthcare providers and systems ratings. Health Care Management Review; Frederick. 41.4:296.

Apenko, S. and Chernobaeva, G. (2016, April). The influence of complex adaptive leadership on the efficiency of business management. International Conference on Management, Leadership \& Governance; Kidmore End. 17-24. Kidmore end: Academic Conferences International Limited.

Aquillio, M. (2016, February). Sarbanes-0xley and the fishing expedition. ASBBS Proceedings. 23.1: 31-40. San Diego: San Diego American Society of Business and Behavioral Sciences.

Baker, C. (2016). CEOs adapt to a brave new world. Credit Control. 37.1/2:6-7.

Bartlett, R. (2016, February). Corporate treasury. Accountancy SA. 42-45.

Buckingham, M. and Coffman, C. (1999). First break all the rules: What the world's greatest managers do differently. New York: Simon \& Schuster.

Butcher, L. (2011, July). Building a great cfo. Charter. 82.6:48.

Caruso, J. (2015, Spring). Business \& industry. Pennsylvania CPA Journal. 86.1:10-11.

Creswell, J. (2003). Research design: Qualitative, quantitative, and mixed methods approaches (2nd ed.). Thousand Oaks, CA: Sage. p. 210.

Creswell, J. (2014). Research design: Qualitative, quantitative, and mixed methods approaches (4th ed.). Thousand Oaks, CA: Sage.

Dembowski, F.L. (2013, January). The roles of benchmarking, best practices \& innovation in organizational effectiveness. International Journal of Organizational Innovation (Online); Hobe Sound. 5.3: 6-20.

Elsbach, K.D. and Bechky, B.A. (2009). Qualitative Organizational Research (Vol. 2). Charlotte, NC. Information Age Publishing, Inc.

Epure, S. and Lupu, L. (2012). Achieving analysis submodels of organizational structure functionality and efficiency. Calitatea, suppl. Access to success Quality: Access is Success: Bucharest. 13.5:141-145.

Eriksson P. and Kovalainen, A. (2008). Qualitative Methods in Business Research. Thousand Oaks, CA: Sage. 
Franklin, M. (2016, July). Sarbanes-Oxley section 404: A historical analysis. Journal of Accounting and Finance. 16.4: 56-59.

Glamuzina, M. (2015, May). Levels of leadership development and top management's effectiveness: Is there a clear-cut relationship?*. Management: Journal of Contemporary Management Issues, suppl. The Life and Work of Professor Emeritus Marin, Split. 20:89.

Grove, C. (2016, February). Growing investor confidence. Accountancy SA. 38-39.

Horne, J.R. (2016). The nine critical questions managers should ask - A proposal for evaluating organizational efficiency. Journal of Strategic Innovation and Sustainability; West Palm Beach. 11.1:20-32.

Howell, B. (2015, February). SEC accounting probes highlights compliance needs. Money Management Executive. 23.5.

Inkinen, H. (2016). Review of empirical research on knowledge management practices and firm performance. Journal of Knowledge Management; Kempston. 20.2:230-257.

Joseph, S.M. (2015, March). Board independence, corporate governance, and fraud: A review of the empirical research and direction for the future. Oil, Gas \& Quarterly. 63.3:433.

Kerns, C.D. (2015, December). Results management: A core leadership dimension. Journal of Leadership, Accountancy and Ethics; Lighthouse Point. 12.5:9-23.

Lin (Jeffrey Frost), Y. and Orvis, B. Principles of management efficiency and organizational inefficiency. Kybernetes; London. 45.8: 1308-1322.

Mahadeva, M. (2015, July/August). Strategic communication. Today's CPA. 43.1:10.

Malbasic, I. Marimon, F and Mas-Machuca, M. (2016). Is it worth having focused values? Management Decision; London. 54.10:2370-2392.

Moulton, D. (2016, August). Finance and it seen as stronger when sharing. Bottom Line. 32.9: 9, 19.

Nardi, P.M. (2003). Doing Survey Research: A Guide to Quantitative Methods. Boston, MA. Allyn and Bacon.

North American Division Working Policy (2015-2016). North American Division of the General Conference; Silver Springs, MD.

Ode, F. (2016, May/June). Who's leading your company? Look for the chief problem officer. Construction Accounting \& Taxation. 26.3:6-10.

Rangriz, H. and Soltanieh, F. (2015). Exploring the effects of organisational capabilities and managerial competencies on the organisational effectiveness. Journal of Strategic Human Resource Management; New Delhi. $4.2: \mathrm{n} / \mathrm{a}$.

Sadeh, E. (2017). Interrelationships among quality enablers, service quality, patients' satisfaction and loyalty in hospitals. TQM Journal; Bingley. 29.1: 101-117.

Salieh, L. and Abu-Doieh, J. (2015). The relationship between total quality management practices and their effects on bank's technical efficiency. International Journal of Commerce and Management; Bingley. 25.2:173-182.

Schiff, J., and Schiff, A. (2016, April). Get in gear! Strategic Finance. 97.10:24-31.

Seventh-day Adventist Accounting Manual, (2011 Edition/January). General Conference of Seventh-day Adventists. Silver Spring, Maryland. p. 4 -7.

Shapiro, D. (2015, May/June). Treasurers under investigation. The Journal of Corporate Accounting \& Finance. 26.4:37-41.

Shiri, S. (2012, June). Strategic role of hr audit in organizational effectiveness. Journal of Management and Public Policy; New Delhi. 3.2: 39-45.

Srivalli, P., Kota, N M K. (2016). Journal of Organization and Human Behaviour; New Delhi. 5.1:n/a.

Taylor, C. M., Cornelius, C.J. and Colvin, K. (2014). Visionary leadership and its relationship to organizational effectiveness. Leadership \& Organization Development Journal; Bradford. 35.6:583-566.

Ullah, I, and Yasmin, R. (2013, August). The influence of human resource practices on internal customer satisfaction and organizational effectiveness. Journal of Internet Banking and Commerce; Ottawa. 18:1-28.

Van Niekerk, P. (2016, February). The evolving role of the cfo. Accountancy SA. 36-37. 
Vercic, D. and Zerfass, A. (2016). A comparative excellence framework for communication management. Journal of Communication Management; London. 20.4: 270-288.

Verma, T. and Dhar, S. (2016, July). The impact of intellectual capital on organizational effectiveness: A comparative study of public and private sectors in india. IUP Journal of Knowledge Management; Hyderadad. 14.3:7-27.

Walter, J. (2014). Leadership styles and effectiveness in small, medium and large organizations. Capella University, ProQuest Dissertations Publishing, 3616067.

Westfall, C. (2015). CFO of the future: Strategy \& substance. Financial Executives. 31.3:50-56.

Yildiz, E. (2014). A study on the relationship between organizational culture and organizational performance and a model suggestion. International Journal of Research in Business and Social Science; Istanbul. 3.4: 52-67. 